\title{
The diversity of annelids in subterranean waters: a case study from Poland
}

\author{
Elzbieta Dumnicka $^{1, *}$, Joanna Galas $^{1}$, Mariola Krodkiewska ${ }^{2}$ and Agnieszka Pociecha ${ }^{1}$ \\ ${ }^{1}$ Institute of Nature Conservation, Polish Academy of Sciences, A. Mickiewicza 33, 31-120 Kraków, Poland \\ ${ }^{2}$ Institute of Biology, Biotechnology and Environmental Protection, University of Silesia, Bankowa 9, 40-007 Katowice, Poland
}

Received: 9 December 2019 / Accepted: 21 February 2020

\begin{abstract}
Not all invertebrate groups commonly occur in subterranean waters but annelids live in surface and underground habitats. The annelid species' richness in various underground waters (wells and interstitial and cave waters) and surface streams of Poland was compared, and the habitat preferences for the most frequent species were determined. Until now, 111 annelid taxa (mainly oligochaetes) had been identified in underground waters in Poland, with higher numbers (71) in the interstitial habitat than in stream bottoms (62). The number of species identified in the caves and wells was distinctly lower (54 and 29 , respectively). The Correspondence Analysis did not separate the samples from various underground water types into distinct groups, and the distribution of well fauna was especially scattered (in the ordination diagram) because abiotic parameters differ strongly in studied wells. Only three stygobiontic species (Cernosvitoviella parviseta, Enchytraeus dominicae and Trichodrilus moravicus) were related to some caves. The analysis of the available data indicate that to obtain a comprehensive picture of the aquatic fauna in a given country all types of subterranean aquatic habitats should be sampled and taken into account. Moreover, to ascertain the composition of benthic invertebrates in running waters, investigation of the interstitial habitat should also be performed.
\end{abstract}

Keywords: Oligochaetes / interstitial waters / wells / cave waters / stream benthos

Résumé - La diversité des annélides dans les eaux souterraines : une étude de cas en Pologne. Tous les groupes d'invertébrés ne sont pas présents dans les eaux souterraines, mais les annélides vivent dans des habitats de surface et souterrains. La richesse des espèces d'annélides dans les différentes eaux souterraines (puits, eaux interstitielles et grottes) et les cours d'eau de surface de Pologne a été comparée, et les préférences d'habitat des espèces les plus fréquentes ont été déterminées. Jusqu'à présent, 111 taxons d'annélides (principalement des oligochètes) ont été identifiés dans les eaux souterraines en Pologne, avec un nombre plus élevé (71) dans l'habitat interstitiel que dans le fond des cours d'eau (62). Le nombre d'espèces identifiées dans les grottes et les puits était nettement plus faible (54 et 29, respectivement). L'analyse des correspondances n'a pas séparé les échantillons des différents types d'eaux souterraines en groupes distincts, et la distribution de la faune des puits était particulièrement dispersée (dans le diagramme d'ordination) car les paramètres abiotiques diffèrent fortement dans les puits étudiés. Seules trois espèces stygobiontiques (Cernosvitoviella parviseta, Enchytraeus dominicae et Trichodrilus moravicus) étaient apparentées à certaines grottes. L'analyse des données disponibles indique que pour obtenir une image complète de la faune aquatique dans un pays donné, tous les types d'habitats aquatiques souterrains doivent être échantillonnés et pris en compte. En outre, pour déterminer la composition des invertébrés benthiques dans les eaux courantes, il convient également de procéder à une étude de l'habitat interstitiel.

Mots clés : oligochètes / eaux interstitielles / puits / eaux souterraines / benthos de rivière

\footnotetext{
*Corresponding author: dumnicka@iop.krakow.pl
} 


\section{Introduction}

Subterranean waters constitute the majority of freshwater resources, but invertebrates inhabit only its relatively shallow level, primarily in unconfined aquifers (Gibert et al., 1994a). These invertebrates can be accessible in caves, springs, and dug and drilled wells. Springs are outflows of underground waters, and typical subterranean species such as stygobionts (obligate subterranean aquatic organisms) can sometimes be found in them (Dumnicka and Galas, 2017). However, due to the character of this biotope, which is similar to other surface water bodies, they are inhabited by the benthic community (along with some species specific for springs). For this reason, springs were not taken into consideration in this paper. Shallow subterranean habitats such as interstitial waters (Juberthie and Decu, 1994; Culver and Pipan, 2009) as well as hypotelminorheic and epikarst waters (Culver and Pipan, 2011) and alluvial mesovoid shallow substratum (Ortuño et al., 2013) also belong to the category of subterranean waters, but the fauna of both these aforementioned habitats was not studied in Poland.

Groundwater fauna consists of: stygobionts - organisms reproducing exclusively in this habitat, stygophiles - species completing their life cycle in both subterranean and surface waters, and stygoxens - species that can accidentally be found in underground water (Pacioglu 2010). These groups have different degrees of adaptation to groundwaters (Gibert et al., 1994b), but even stygobionts can be found occasionally in surface waters (Krzanowski et al., 1965; Dumnicka et al., 2018). Composition of invertebrate benthic fauna in surface and subterranean waters differs significantly: non-insect species (mainly crustaceans, water mites and annelids) are the most abundant and diverse in underground waters (e.g., Sket, 1999; Košel, 2009; Martin et al., 2009; Chertoprud et al., 2016), while insect fauna is usually rich in the benthos of nonpolluted stagnant and running surface waters of Europe (Starmach et al., 1976; Dijkstra et al., 2014). The differences between the composition of bottom and interstitial macroinvertebrate fauna are often small (Mary and Marmonier, 2000; Meleg et al., 2009), but the larvae of insects are sometimes scarce in the interstitial habitat (Danielopol, 1984, Creuzé des Châtelliers et al., 1992).

In Poland, one of the most studied groups living in subterranean waters (including small, temporary pools occurring in caves, principally in the Kraków-Częstochowa Upland) are annelids. Studies on this taxonomic group started at the end of the 19th century when Jaworowski (1893) found a few species in municipal wells in Kraków. Only eighty years later, Kasprzak (1973a,b) published new data from a number of wells situated in various regions of Poland. More extensive studies were conducted by Dumnicka (2000) and Dumnicka et al. (2017) on oligochaetes in this habitat. The first information about the presence of oligochaetes in caves was published by Demel (1918), who found only a singular lumbricid taxon. From $30 \mathrm{yr}$ in the 20th century, cave annelids were studied by Pax \& Maschke (1935), Moszyński (1936) and Stammer (1936) in the Sudetes, whereas Skalski (1967), Kasprzak (1973b) and Kasprzak \& Zajonc (1980) published information about this group from singular caves located in the Tatra Mountains. The majority of data concerning oligochaetes from many Polish caves were elaborated on by Dumnicka and
Table 1. Number of analysed objects and number of publications concerning particular subterranean habitats. In some papers, results obtained from two or three different habitats were included.

\begin{tabular}{lll}
\hline Habitat & $\begin{array}{l}\text { Number of } \\
\text { studied objects }\end{array}$ & $\begin{array}{l}\text { Number of } \\
\text { publications }\end{array}$ \\
\hline Wells & circa 70 & 7 \\
Caves & 31 & 24 \\
Interstitial waters & 46 & 8 \\
Water works & 2 & 2 \\
\hline
\end{tabular}

co-workers (Dumnicka, 2000 (in this paper 11 previous publications of this author were cited) Dumnicka, 2003, 2009; Dumnicka et al., 2015, 2016). A few data sets available from artificial subterranean spaces such as adits or quarries (Moszyński 1936; Dumnicka 1996) are included with data from caves in this paper. The studies on annelid fauna of interstitial waters began in the second half of the 20th century, but this habitat was intensively investigated in following years (Kasprzak, 1973a,b,c; 1975, 1976, 1979a,b; Dumnicka, 2000; Dumnicka et al., 2018). In Poland, very few studies dealing with annelids were conducted in the waterworks systems (Moszyński, 1934; Pawłowski, 1951) directly connected with underground waters, which are sometimes inhabited by numerous and diverse invertebrates (Luczak et al., 1980).

Aims:

The present study summarizes all available published information on annelids inhabiting subterranean aquatic habitats in Poland in order to determine (1) whether there is a difference in annelid composition among different habitats; and (2) what factors influence annelid species richness and their habitat references

\section{Material and methods}

In this study data from 38 papers concerning oligochaetes studied in four subterranean habitats have been used (Tab. 1, Fig. 1). Sometimes a few sampling stations were studied in the same cave, this also applies to particular running waters. The majority of papers dealing with oligochaeta composition from subterranean waters resulted from qualitative samples collected using a bottom scraper. Much less frequently quantitative samples have been collected using the Ekman sampler or a bottom scraper. In both the methods, the collected sediments were washed using nets with various mesh size. Fauna samples from interstitial waters were collected from holes $(40-50 \mathrm{~cm}$ deep), which were dug in sediments on the river border (Karaman-Chappuis method). Specimens from samples of all types were sorted using a stereoscopic microscope or with naked eyes. Especially in previous papers, methods are not strictly described. From various localities samples were collected once or several times.

In analysed papers usually the total number of collected specimens or their relative abundance e.g. "high number", "numerous", "fairly numerous" etc. or the relative scale was used (Tab. 2). In Table 3, the number of records represents the number of species findings in particular subterranean aquatic 


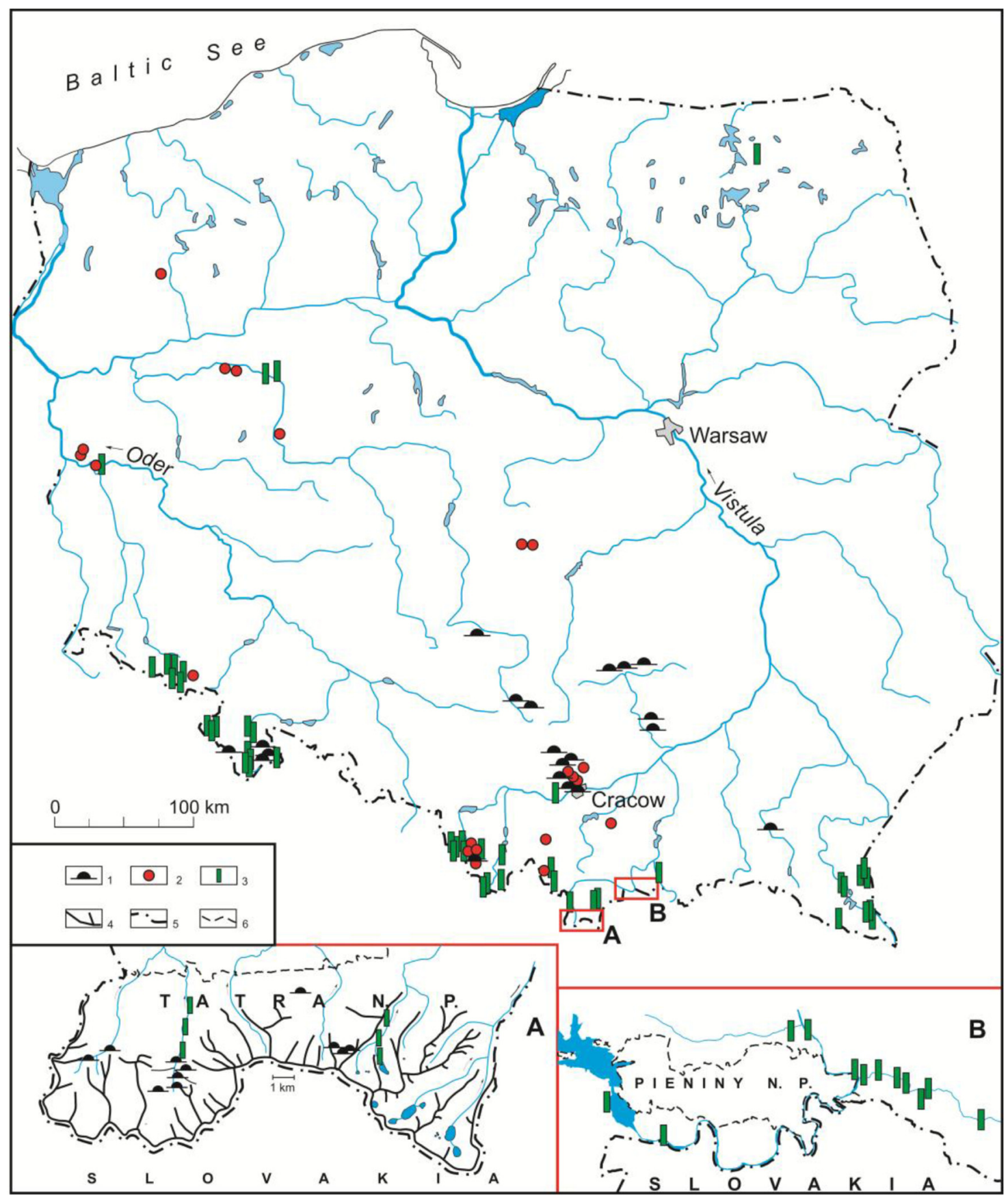

Fig. 1. The map of Poland showing the distribution of studied habitats; the areas of the Tatra Mts (A) and Pieniny Mts (B) are enlarged. 1-caves, 2-wells, 3-interstitial waters, 4-mountain ranges, 5-country border, 6-national park border.

Table 2. Relative abundance description sheet for Annelida taxa.

\begin{tabular}{ll}
\hline Description & Relative abundance scale \\
\hline Single individuals & 1 \\
Low abundance & 2 \\
Medium abundance & 3 \\
Abundant & 4 \\
Very abundant & 5 \\
\hline
\end{tabular}

habitats. The samples without annelids were not taken into account.

Systematics of Annelida according to Fauna Europaea (www.fauna-eu.org) as well as Kahl and Pilipiuk (2004) was used.

\subsection{Data analysis}

In statistical analyses, the waterworks were not included because the data came only from two localities (the municipal 
E. Dumnicka et al.: Knowl. Manag. Aquat. Ecosyst. 2020, 421, 16

Table 3. Number of annelid species in various subterranean habitats. In streams benthic and interstitial annelids fauna was studied.

\begin{tabular}{|c|c|c|c|c|c|c|}
\hline \multirow[t]{2}{*}{ Taxa } & \multirow[t]{2}{*}{ Bottom sedim. } & \multicolumn{5}{|c|}{ Subterranean habitats } \\
\hline & & $\Sigma$ records & $\begin{array}{l}\text { Interst. } \\
\text { waters }\end{array}$ & $\begin{array}{l}\text { Cave } \\
\text { waters }\end{array}$ & Wells & $\begin{array}{l}\text { Waterworks } \\
\text { device }\end{array}$ \\
\hline
\end{tabular}

Polychaeta

Hrabeiella periglandulata Pižl \& Chalupsky, 1984

Troglochaetus beranecki Delachaux, 1921

Aphanoneura

Potamodrilus fluviatilis Lastočkin, 1935

Aeolosoma sp. Ehrenberg, 1831

Aeolosoma niveum Leydig, 1865

Aeolosoma tenebrarum Vejdovsky, 1880

Oligochaeta

Propappus volki Michaelsen, 1916

Achaeta eiseni Vejdovsky, 1877

Achaeta seminalis Kasprzak, 1972

Bryodrilus ehlersi Ude, 1892

Buchholzia appendiculata (Buchholz, 1862)

Cernosvitoviella atrata (Bretscher, 1903)

Cernosvitoviella carpatica Niel. \& Christ., 1959

Cernosvitoviella minor Dózsa-Farkas, 1990

Cernosvitoviella parviseta Gadzinska, 1974

Cernosvitoviella tatrensis (Kowalewski, 1916)

Cognettia anomala (Cernosvitov, 1928)

Cognettia glandulosa (Michaelsen, 1888)

Cognettia sphagnetorum (Vejdovsky, 1877)

Enchytraeus albidus Henle, 1837

Enchytraeus buchholzi Vejdovsky, 1879

Enchytraeus christenseni Dózsa-Farkas, 1992

Enchytraeus dominicae Dumnicka, 1976

Enchytraeus lacteus Niel. \& Christ., 1961

Enchytraeus mariae Kasprzak, 1973

Enchytraeus norvegicus Abrahamsen, 1969

Enchytraeus polonicus Dumnicka, 1977

Fridericia bisetosa (Levinsen, 1884)

Fridericia bulbosa (Rosa, 1887)

Fridericia galba (Hoffmeister, 1843)

Fridericia leydigi Vejdovsky, 1877

Fridericia maculata Issel, 1904

Fridericia paroniana Issel, 1904

Fridericia perrieri (Vejdovsky, 1877)

Fridericia ratzeli (Eisen, 1872)

Fridericia semisetosa Dózsa-Farkas, 1970

Fridericia tubulosa Dózsa-Farkas, 1972

Henlea gubleri Bretscher, 1903

Henlea nasuta (Eisen, 1878)

Henlea perpusilla Friend, 1911

Henlea similis Niel.\& Christ., 1959

Henlea ventriculosa (d'Udekem, 1854)

Lumbricillus rivalis (Levinsen, 1884)

Marionina argentea (Michaelsen, 1889)

Marionina libra Niel. \& Christ., 1959

Marionina riparia Bretscher, 1899

Marioniana spicula (Leuckart, 1847)

Mesenchytraeus armatus (Levinsen, 1884) 
Table 3. (continued).

\begin{tabular}{|c|c|c|c|c|c|c|}
\hline \multirow[t]{2}{*}{ Taxa } & \multirow[t]{2}{*}{ Bottom sedim. } & \multicolumn{5}{|c|}{ Subterranean habitats } \\
\hline & & $\Sigma$ records & $\begin{array}{l}\text { Interst. } \\
\text { waters }\end{array}$ & $\begin{array}{l}\text { Cave } \\
\text { waters }\end{array}$ & Wells & $\begin{array}{l}\text { Waterworks } \\
\text { device }\end{array}$ \\
\hline Chaetogaster diastrophus (Gruith., 1828) & 1 & 2 & 1 & 1 & & \\
\hline Chaetogaster langi Bretscher, 1896 & & 1 & & & & 1 \\
\hline Nais alpina Sperber, 1948 & 2 & 3 & 2 & & 1 & \\
\hline Nais barbata O.F. Muller, 1774 & 1 & 1 & 1 & & & \\
\hline Nais bretscheri Michaelsen, 1899 & 1 & 3 & 3 & & & \\
\hline Nais communis Piguet, 1906 & 6 & 12 & 6 & 3 & 3 & \\
\hline Nais elinguis O.F. Muller, 1774 & 14 & 17 & 14 & 2 & & 1 \\
\hline Nais pardalis Piguet, 1906 & 2 & 2 & 2 & & & \\
\hline Nais pseudobtusa Piguet, 1906 & 2 & 2 & 2 & & & \\
\hline Nais simplex Piguet, 1906 & 2 & 3 & 2 & & 1 & \\
\hline Nais variabilis Piguet, 1906 & 1 & 3 & 1 & 1 & & 1 \\
\hline Ophidonais serpentina (O.F. Muller, 1774) & & 1 & 1 & & & \\
\hline Pristina bilobata (Bretscher, 1903) & 5 & 5 & 5 & & & \\
\hline Pristina aequiseta Bourne, 1891 & 29 & 33 & 29 & & 3 & 1 \\
\hline Pristina jenkinae Stephenson, 1932 & & 1 & & 1 & & \\
\hline Pristina longiseta Ehrenberg, 1828 & 1 & 4 & 4 & & & \\
\hline Pristina menoni Aiyer, 1929 & 29 & 32 & 29 & 1 & 2 & \\
\hline Slavina appendiculata (d'Udekem, 1855) & & 2 & 1 & & 1 & \\
\hline Vejdovskyella intermedia (Bretscher, 1896) & & 1 & & 1 & & \\
\hline Aulodrilus pluriseta (Piguet, 1906) & 1 & 1 & 1 & & & \\
\hline Edukemius benedi (d'Udekem, 1855) & 3 & 4 & 3 & & 1 & \\
\hline Gianius aquaedulcis (Hrabě, 1960) & 1 & & & & & \\
\hline Haber zavreli (Hrabě, 1942) & & 3 & & & 3 & \\
\hline Ilyodrilus templetoni (Southern, 1909) & 1 & 1 & 1 & & & \\
\hline Limnodrilus sp. juv. Claparède, 1862 & & 1 & & 1 & & \\
\hline Limnodrilus claparedeanus Ratzel, 1869 & 2 & 2 & 2 & & & \\
\hline Limnodrilus hoffmeisteri Claparède, 1862 & 8 & 8 & 8 & & & \\
\hline Limnodrilus udekemianus Claparède, 1862 & 1 & 2 & 2 & & & \\
\hline Epirodrilus pygmaeus (Hrabě, 1935) & 2 & 2 & 2 & & & \\
\hline Potamothrix hammoniensis (Michaelsen, 1901) & 1 & 2 & 2 & & & \\
\hline Potamothrix moldaviensis Vejd. \& Mrazek, 1903 & 1 & 2 & 1 & & 1 & \\
\hline Psammoryctides albicola (Michael., 1901) & 3 & 3 & 3 & & & \\
\hline Psammoryctides barbatus (Grube, 1861) & 1 & 1 & 1 & & & \\
\hline Rhyacodrilus coccineus (Vejdovsky, 1876) & 4 & 7 & 6 & & 1 & \\
\hline Rhyacodrilus falciformis Bretscher, 1901 & & 3 & & 3 & & \\
\hline Rhyacodrilus subterraneus Hrabě, 1963 & & 2 & 1 & & 1 & \\
\hline Spirosperma ferox (Eisen, 1879) & 3 & 4 & 4 & & & \\
\hline Tubifex ignotus (Štolc, 1886) & & 1 & & 1 & & \\
\hline Tubifex tubifex (O.F. Muller, 1774) & 6 & 10 & 6 & 2 & 2 & \\
\hline Lumbriculus variegatus (O.F. Muller, 1774) & 12 & 14 & 12 & 2 & & \\
\hline Rhynchelmis sp. juv. Hoffmeister, 1843 & & 1 & 1 & & & \\
\hline Stylodrilus brachystylus Hrabě, 1929 & 1 & 4 & 3 & & 1 & \\
\hline Stylodrilus heringianus Claparède, 1862 & 16 & 19 & 16 & 3 & & \\
\hline Stylodrilus parvus (Hrabě \& Cernosvitov, 1927) & & 1 & & 1 & & \\
\hline Trichodrilus sp. juv. Claparède, 1862 & & 1 & & & 1 & \\
\hline Trichodrilus cernosvitovi Hrabě, 1937 & 1 & 2 & 2 & & & \\
\hline Trichodrilus moravicus Hrabě, 1937 & 2 & 7 & 2 & 4 & 1 & \\
\hline Trichodrilus pragensis Vejdovsky, 1876 & & 2 & & 2 & & \\
\hline Trichodrilus spelaeus Moszyński, 1936 & & 1 & & 1 & & \\
\hline Haplotaxis gordioides (Hartmann, 1821) & 18 & 25 & 18 & 4 & 3 & \\
\hline Dendrobaena sp. Eisen, 1874 & & 1 & & 1 & & \\
\hline Dendrodrilus rubidus (Savigny, 1826) & & 2 & & 2 & & \\
\hline Eisenia fetida (Savigny, 1826) & & 1 & & & 1 & \\
\hline Eiseniella tetraedra (Savigny, 1826) & 1 & 3 & 1 & 1 & 1 & \\
\hline Lumbricus terrestris L., 1758 & & 1 & & & 1 & \\
\hline
\end{tabular}


Table 3. (continued).

\begin{tabular}{|c|c|c|c|c|c|c|}
\hline \multirow[t]{2}{*}{ Taxa } & \multirow[t]{2}{*}{ Bottom sedim. } & \multicolumn{5}{|c|}{ Subterranean habitats } \\
\hline & & $\Sigma$ records & $\begin{array}{l}\text { Interst. } \\
\text { waters }\end{array}$ & $\begin{array}{l}\text { Cave } \\
\text { waters }\end{array}$ & Wells & $\begin{array}{l}\text { Waterworks } \\
\text { device }\end{array}$ \\
\hline \multicolumn{7}{|l|}{ Hirudinea } \\
\hline Erpobdella octoculata (L., 1758) & & 1 & & & & 1 \\
\hline Erpobdella nigricollis (Brandes, 1900) & & 1 & & & & 1 \\
\hline Glossiphonia complanata (L., 1758) & & 1 & & & & 1 \\
\hline Helobdella stagnalis (L., 1758) & & 1 & & & & 1 \\
\hline$\sum$ & 250 & 489 & 280 & 151 & 49 & 10 \\
\hline
\end{tabular}

waterworks in Warsaw and Poznań cities). An indirect analysis (a correspondence analysis), based on the relative abundance of annelid species, was carried out using CANOCO for Windows version 4.5 (Ter Braak and Šmilauer, 2002) in order to inspect the distribution of species in the different underground water types. An indirect analysis (a correspondence analysis) was also calculated to estimate the distribution of oligochaetes in interstitial water and bottom sediments in the studied rivers. Only the individuals identified to a species level were included in the data matrix. Species in which the frequency was less than 5\% were removed from the analysis to reduce noise in the data set. The results from the analysis were displayed graphically in an ordination diagram using the software program CanoDraw ver. 4.12.

Differences in the number of oligochaete species between the studied types of underground water were tested using the Kruskal-Wallis ANOVA and a multiple comparison post hoc test because the biological data did not reveal a normal distribution. The significance of the difference in the number of oligochaete species between interstitial water and bottom sediments in rivers was evaluated using the Student's t-test. The Pearson chi-square test was used to assess whether the frequency of the stygobiontic species occurrence in the compared types of underground waters deviated from a random pattern. The analysis could only be carried out for Enchytraeus dominicae, as the remaining stygobiontic species were present in too few samples. All calculations were performed using the software program Statistica for Windows ver. 13.1.

Species accumulation curves were calculated and constructed using the incidence-based coverage estimator (ICE) and $\mathrm{S}_{\mathrm{obs}}$ (calculated according to the Mao Tao function procedures (Colwell, 2013)). The calculation was computed using Estimate $\mathrm{S}$ version 9.1. 0 for Windows with randomization 100 times without replacement.

\section{Results}

Investigations of annelid fauna in the subterranean habitats of Poland were performed mainly in the southern part of country and concentrated in the Tatra and Pieniny Mts. (Fig. 1). The number of studies conducted in central and northern part of Poland (where the caves are generally absent) was distinctly lower. Only about ten papers (from 38) deal with subterranean waters of Central and Northern parts of Poland where the caves are generally absent.
Until now, 111 annelid taxa have been found in subterranean waters of Poland, with many species found exclusively in one or two localities (Tab. 3). The species accumulation curves for the studied underground localities did not reach a plateau but continued to increase (as evidenced by the curve for the $S_{\text {obs }}$ ), indicating that not all annelid species were collected during sampling (Fig. 2).

Freshwater- and soil-dwelling Polychaeta are represented in Poland by only two species, both known from the underground waters (Fig. 3). From 13 species of Aphanoneura, only four taxa have been found in the subterranean environment, while Oligochaeta were represented by 100 taxa among 216 aquatic and terrestrial species known from Poland. Only in the Lumbriculidae family all species known from Poland were found in subterranean waters while in surface habitats (Fig. 3) stygobionts (four species) are missing. In other families, various numbers of species were identified in underground habitats: Tubificidae occurred at almost $60 \%$, Naididae and Enchytraeidae at approximately $48 \%$ and $44 \%$ respectively, along with the smallest number from the family Lumbricidae, which accounted for approximately $16 \%$ of species. Leeches were absent in the wells, interstitial and cave waters; only four species belonging to two families from this group (Fig. 3) have been found in municipal waterworks. Among five classes of Annelida, only Branchiobdellea were not found in the subterranean environment in Poland.

The most numerous records (280) were collected in interstitial waters (Tab. 3), and the highest number of species (71) was found in this habitat as well. Benthic annelids, which were studied parallel to interstitial fauna, were found to have only 62 species present; however, the differences related to the mean species number found in these habitats were statistically insignificant $(t=4.678571 ; \mathrm{d} f=110 ; p>0.05)$. The correspondence analysis (CA) did not indicate a division of the samples from interstitial waters and bottom sediments in the studied rivers - these samples overlap in the graph in most cases (Fig. 4). The number of species found in the caves and wells is distinctly lower (54 and 29 species, respectively) than that from the interstitial habitat (Tab. 3). Similarly, the number of records from these habitats is lower than that from interstitial waters. The Kruskal-Wallis ANOVA test revealed statistically significant differences in the median number of species between the types of underground waters $(H=13.49893 ; p=0.0012)$. However, multiple comparison post hoc tests showed statistically significant differences in the median number of species only between interstitial waters and 


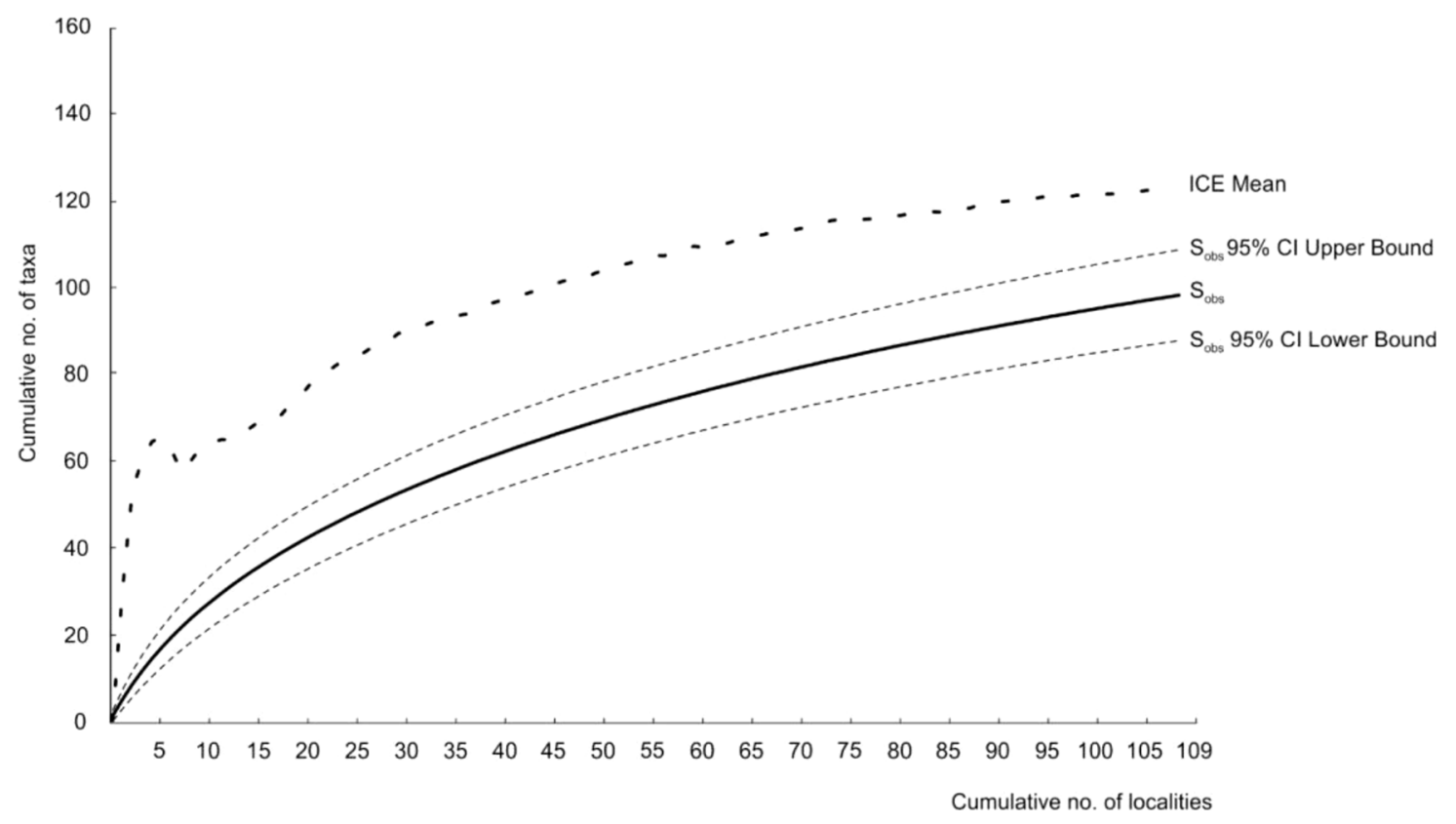

Fig. 2. Species accumulation curves and sample-based species richness estimator for study underground localities $\left(\mathrm{S}_{\mathrm{obs}}-\right.$ the total number of taxa in the polled samples calculated according to the Mao-Tau function, $95 \% \mathrm{Cl}-95 \%$ confidence limit for $\mathrm{S}_{\text {obs }}$, ICE mean - incidence-based coverage estimator).

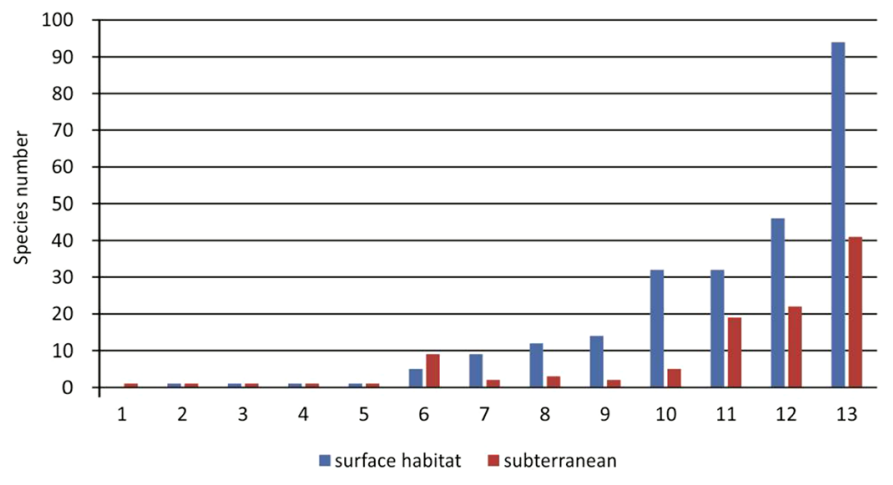

Fig. 3. Number of species (from various families) found in surface (blue bars) vs. underground (red bars) habitats:1-Nerillidae, 2-Parergodrilidae, 3-Potamodrilidae, 4-Propappidae, 5-Haplotaxidae, 6-Lumbriculidae, 7-Erpobdellidae, 8-Aeolosomatidae, 9-Glossiphoniidae, 10-Lumbricidae, 11-Tubificidae, 12-Naididae, 13-Enchytraeidae.

two other underground water types (caves and wells). Only nine annelid species have been found in waterworks systems, but this habitat was studied sporadically (with 10 records).

The correspondence analysis (CA), conducted on the grounds of the relative abundance of oligochaete species, did not separate the samples of the studied underground water types into distinct groups (Fig. 5). In particular, the samples from wells are not clustered and are scattered on the diagram. The portion of samples from interstitial waters, located on the left side of the first axis in the graph, forms a separate group. It consists of species such as Limnodrilus hoffmeisteri, Propappus volki, Stylodrilus heringianus, Nais elinguis, Haplotaxis gordioides, Lumbriculus variegatus, Pristina menoni, $P$. aequiseta, Rhyacodrilus coccineus and Tubifex tubifex. However, three stygobiontic species (Cernosvitoviella parviseta, Enchytraeus dominicae and Trichodrilus moravicus) (situated in the lower right side of the diagram) are related to some caves (Fig. 5), but only the occurrence of $E$. dominicae was more frequent in the caves (Pearson $\chi^{2}=18.98027 ; \mathrm{d} f=3$; $p<0.001)$. The results of the CA showed that the first two ordination axes explained $24.8 \%$ of the variability in the species data from the studied underground water types.

\section{Discussion}

According to Kahl and Pilipiuk (2004), 280 annelid species are known in Poland, and almost $40 \%$ of them have been found in subterranean waters. The species accumulation curves for the studied underground localities did not reach a plateau (as evidenced by the curve for the $\mathrm{S}_{\text {obs }}$ ) indicating that not all annelid species were collected during sampling. Future studies should be primarily conducted in wells, since these structures reach subterranean waters in various geological layers, what is especially important in the regions without caves. In Poland, these areas are the least studied, particularly in the northern part of the country (Dumnicka and Galas, 2017).

A substantial number of species were found in a single or only a few localities, but the group of such species is heterogeneous. First, the majority of stygobionts are known from one or only a few localities in Poland (Dumnicka and Galas, 2017) besides numerous studies conducted in interstitial and cave waters. A good example is Troglochaetus beranecki, which was only found by Stammer (1936) in the Kłodzko Basin and was never found again despite intensive studies 


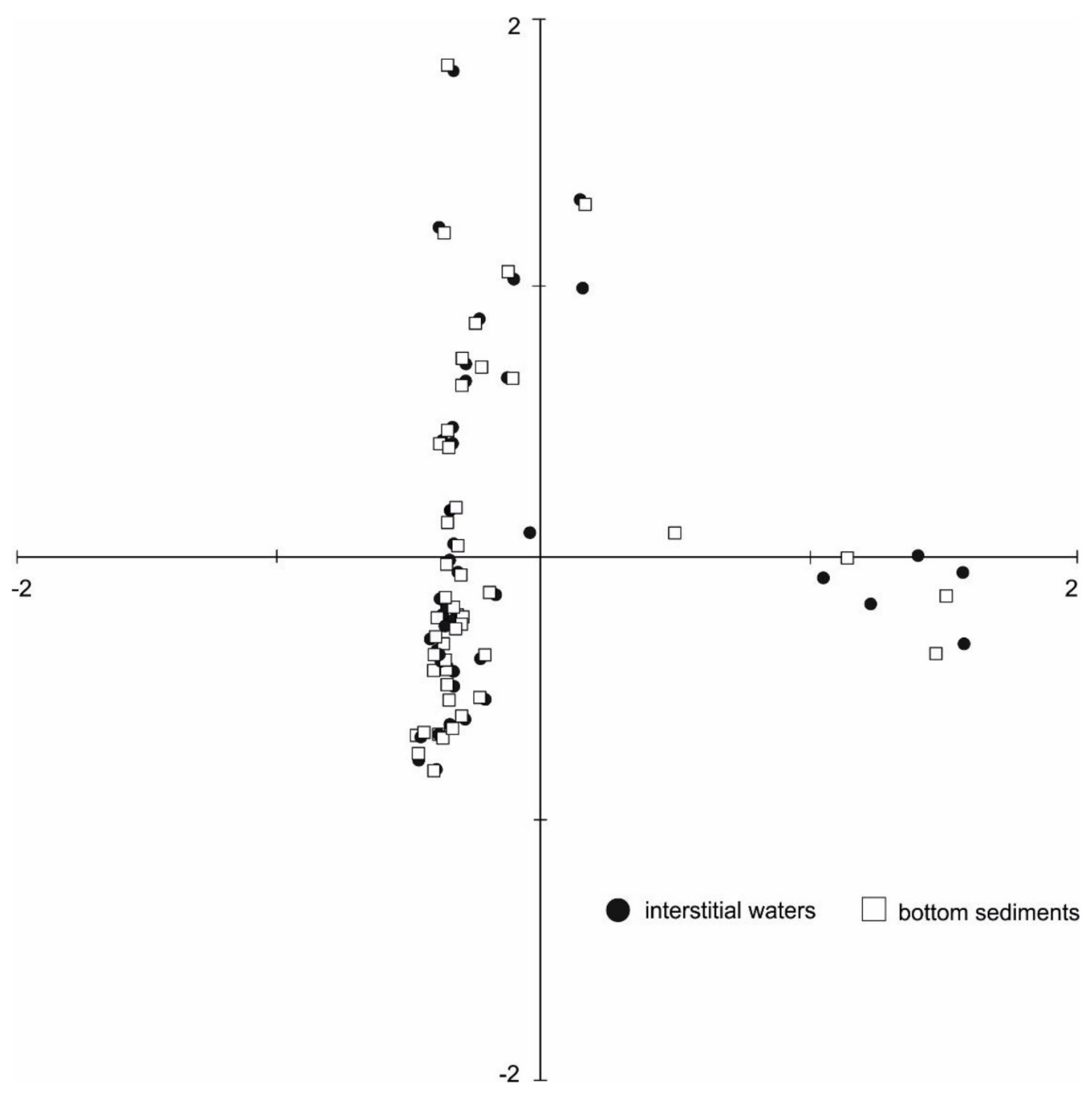

Fig. 4. Correspondence analysis (CA) ordination diagram with only plotted samples from interstitial waters and bottom sediments in the rivers.

conducted by Hajduk and Ogorzałek (1978), Sywula (1989), Dumnicka (2000), and Skalski (personal comm.) in this area. Stygobiontic species belonging to various taxonomic groups, not only annelids, are infrequently caught, so some species are exclusively known from type locality, such as Trichodrilus spelaeus (Moszyński, 1936), or from a few localities, like Niphargus casimiriensis (Skalski, 1980). Such a situation has been identified in other countries as well (Martin et al., 2009; Giani et al., 2011; Chertoprud et al., 2016). Second, some rare species as Hrabeiella periglandulata, Potamodrilus fluviatilis, Chaetogaster langi, Epirodrilus pygmaeus (Kahl and Pilipiuk, 2004), as well as endemic species, are found in singular localities in Polish subterranean waters. Third, many common benthic species are only accidentally discovered in underground habitats. In particular, this includes species feeding on algae (e.g., many representatives of Naididae) or characteristic for lakes and lowland rivers with muddy bottoms (genus Potamothrix, Psammoryctides barbatus). Moreover, among typically terrestrial enchytraeids (from genera Achaeta, Fridericia or Henlea) some species have been found in a few localities in permanent or temporary subterranean water bodies. The presence of soil dwelling species from that family was also identified in the aquatic underground habitat by other investigators (Giani et al., 2011; Martínez-Ansemil et al., 2016). Finally, a small number of records concerning lumbricids and leech species is caused by scarce occurrence of the first family (except for Eiseniella tetraedra) and a lack of Hirudinea in natural subterranean waters of Poland, however representatives of this last mentioned group were occasionally found in cave waters (Sket et al., 2001).

Among the studied habitats, the highest richness of annelid fauna was identified in interstitial waters. A few factors seem to be responsible for this phenomenon. First, the highest number of records comes from this habitat. Furthermore, interstitial waters could be a refuge for various invertebrates during extreme hydrological events such as drought or flood (Wood et al., 2010; Stubbington, 2012). Moreover, lower predator pressure and higher amounts of organic matter exist in interstitial waters compared to deeper subterranean waters (Williams et al., 2010), facilitating survival of many benthic taxa (including oligochaetes) there. This is why their total number (Williams and Hynes, 1974; Olsen and Townsend, 2005) 


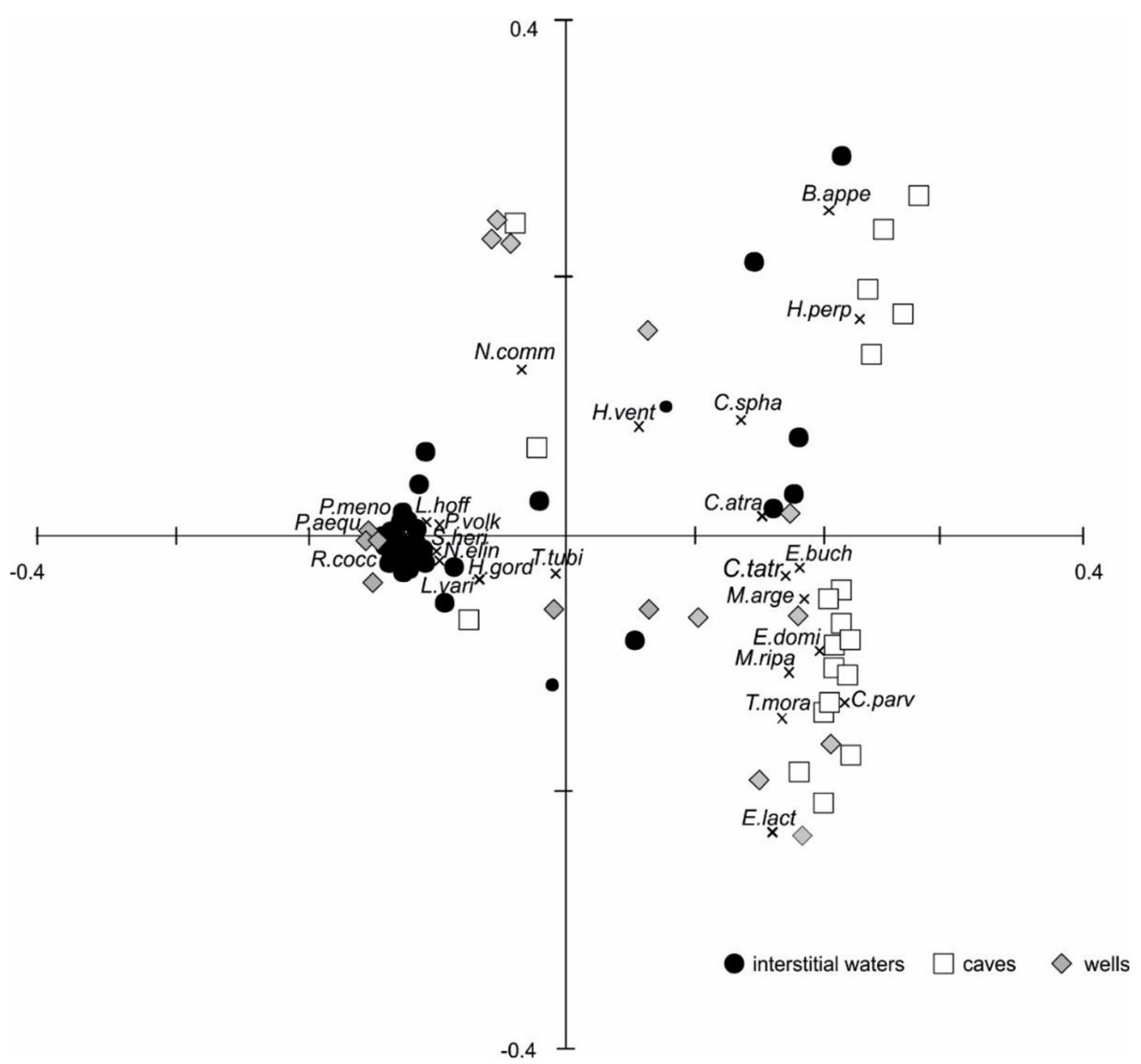

Fig. 5. Correspondence analysis (CA) ordination diagram with plotted samples and species of Oligochaeta from the studied underground water types. Abbreviations: B.appe- Buchholzia appendiculata, C.atra- Cernosvitoviella atrata, C.parv- Cernosvitoviella parviseta, C.tatrCernosvitoviella tatrensis, C.spha- Cognettia sphagnetorum, E.buch- Enchytraeus buchholzi, E.domi- Enchytraeus dominicae, E.lactEnchytraeus lacteus, H.gord- Haplotaxis gordioides, H.perp- Henlea perpusilla, H.vent- Henlea ventriculosa, L.hoff- Limnodrilus hoffmeisteri, L.vari- Lumbriculus variegatus, M.arge- Marionina argentea, M.ripa- Marionina riparia, N.comm- Nais communis, N.elin- Nais elinguis, P. aequ- Pristina aequiseta, P.meno- Pristina menoni, P.volk- Propappus volki, R.cocc- Rhyacodrilus coccineus, S.heri- Stylodrilus heringianus, T. mora- Trichodrilus moravicus, T.tubi- Tubifex tubifex.

or frequency (Mary and Marmonier, 2000) could be higher than in benthos. In some Polish rivers, where annelid fauna was studied in both these habitats (Kasprzak, 1973a,b; Dumnicka, 2000), species richness was higher in interstitial waters, what confirms the importance of this habitat for benthic organisms.

The statistical analysis (CA) did not separate the samples of underground water types into distinct groups (Fig. 5), and the distribution of well-based fauna is especially scattered on the graph because abiotic parameters differ strongly in these habitats. In shallow open wells and in wells situated in river valleys, benthic taxa from various taxonomic groups were typically identified (Kasprzak, 1973a,b; Knight et al., 2015; Dumnicka et al., 2017), whereas in fairly deep wells supplied by infiltrating waters, annelids and crustaceans were mainly found (Dumnicka et al., 2017). In general, benthic species also occurred in surface streams flowing through the caves, such as Skorocicka Cave (Dumnicka and Wojtan, 1993) or Wodna pod Pisaną Cave (Dumnicka and Galas, 1997) and in water bodies situated near cave entrances (Chertoprud et al., 2016), since it is easy for organisms to migrate and settle into these locations. However, in water bodies situated deep inside the caves, the number of oligochaete species was usually low, and stygobiontic species were found more often. Statistical analyses confirmed this for Enchytraeus dominicae only, because other stygobionts have only been caught sporadically, as mentioned above.

Aquatic and amphibious annelids species living on the bottom or in sediments are principally eyeless and detritivorous, so they are pre-adapted to subterranean life. Many species, especially those most frequently found in the underground habitat, could undergo their whole life cycle there, as indicated by findings of both juvenile and mature specimens or the chains of zooids of some Naididae species. These species belong to various families, including Haplotaxis gordioides (Haplotaxidae), Stylodrilus heringianus, Lumbriculus variegatus (Lumbriculidae), Propappus volki (Propap- 
pidae), Pristina aequiseta, P. menoni, Nais elinguis, (Naididae), Enchytraeus buchholzi, and Marionina argentea (Enchytraeidae). These species are stygophiles; most of them prefer interstitial waters, but the latter two species were found mainly in caves. It is highly probable that some other enchytraeid taxa such as Buchholzia appendiculata, Marionina riparia and those representing the genus Cernosvitoviella are also stygophiles.

The results of available data analyses indicated that subterranean waters should be taken into account to recognize the whole diversity of annelids and other groups such as crustaceans and water mites, including subterranean waters that will prevent stygobionts from being overlooked. Moreover, investigations of the interstitial habitat should also be considered to obtain the composition of benthic invertebrates in running waters. Increasing human pressure on subterranean waters threatens the existence of stygobiontic and rare species; therefore, further studies on the distribution of these species are needed, and the subterranean diversity hot spots should be protected. In view of mounting threats faced by organisms living in this most widespread nonmarine environment on Earth, Mammola et al. (2019) advocated the necessity to promote in the general audience activities raising awareness about them.

\section{References}

Chertoprud ES, Palatov DM, Borisov RR, Marinskiy VV, Bizin MS, Dbar RS. 2016. Distribution and a comparative analysis of the aquatic invertebrate fauna in caves of the western Caucasus. Subterr Biol 18: 49-70.

Colwell RK. 2013. Estimates: Statistical estimation of species richness and shared species from samples. Version 9. User's Guide and application published at: http://purl.oclc.org/estimates

Creuzé des Châtelliers P, Marmonier P, Dole-Oliver MJ, Castella E. 1992. Structure of interstitial assemblages in a regulated channel of the River Rhine (France). Regulated Rivers Res Manag 7: 23-30.

Culver DC, Pipan T. 2009. The biology of caves and other subterranean habitats. Oxford: University Press.

Culver DC, Pipan T. 2011. Redefining the extent of the aquatic subterranean biotope - shallow subterranean habitats. Ecohydrology 4: 721-730.

Danielopol DL. 1984. Ecological investigations on the alluvial sediments of the Danube in the Vienna area - a phreatobiological project. Verh Internat Verein Limnol 22: 1755-1761.

Demel K. 1918. Fauna jaskiń Ojcowskich. Spraw Posiedzeń Tow Nauk Warsz Wydziat Mat-Przyr 11(4): 623-659.

Dijkstra K-DB, Monaghan MT, Pauls SU. 2014. Freshwater biodiversity and insect diversification. Ann Rev Entomol 59: 143-163.

Dumnicka E. 1996. Aquatic Oligochaeta and Aphanoneura from the souterrains of central Europe with description of a new Enchytraeus species. Mém Biospéol 23: 167-171.

Dumnicka E. 2000. Studies on Oligochaeta taxocens in streams, interstitial and cave waters of southern Poland with remarks on Aphanoneura and Polychaeta distribution. Acta zool cracov 43: 339-392.

Dumnicka E. 2003. Observations on the distribution of aquatic fauna in Tatra Mountain caves. Subterr Biol 1: 49-55.
Dumnicka E. 2009. Diversity of oligochaete fauna inhabiting epigean and hypogean sectors of the stream flowing through a non-karstic cave in Beskidy Mts. (Poland). Subterr Biol 7: 41-46.

Dumnicka E, Galas J. 1997. The relationship between Oligochaeta, particulate organic matter and environmental conditions in epigean and hypogean parts of a mountain stream in Poland. Mém Biospéol 24: 9-14.

Dumnicka E, Galas J. 2017. An overview of stygobiontic invertebrates of Poland based on published data. Subterr Biol 23: $1-18$.

Dumnicka E, Wojtan K. 1993. Invertebrates (with special regard to Oligochaeta) of the semi-underground water bodies in the gypsum caves. Mém Biospéol 20: 63-67.

Dumnicka E, Galas J, Karlikowska J, Sznober N. 2015. Temporary co-existence of aquatic and terrestrial invertebrates in shallow periodically flooded and frozen cave. Biologia 70: 1201-1209.

Dumnicka E, Chabrowska A, Szokalski M. 2016. Fauna bezkręgowców w wypływie z Jaskini w Lelowie (Wyżyna Małopolska). Ziemia Częstochowska 42: 145-156.

Dumnicka E, Galas J, Krodkiewska M. 2017. Patterns of benthic fauna distribution in wells: the role of anthropogenic impact and geology. Vadose Zone J 16: 1-9.

Dumnicka E, Konopacka A, Zurek R. 2018. Changes in the benthic fauna composition in the Upper Vistula over the last 50 years - the consequences of the water pollution reduction and alien species invasion. Oceanol Hydrobiol Stud 47: 303-312.

Giani N, Sambugar B, Martinez-Ansemil E, Martin P, Schmelz RM. 2011. The groundwater oligochaetes (Annelida, Clitellata) of Slovenia. Subterr Biol 9: 85-102.

Gibert J, Danielopol DL, Stanford JA. 1994a. Groundwater ecology. London: Academic Press.

Gibert J, Stanford JA, Dole-Olivier M-J, Ward JV. 1994b. Basic attributes of groundwater ecosystems and prospects for research. In: Gibert J, Danielopol DL, Stanford JA. Eds. Groundwater ecology. London: Academic Press, 7-40.

Hajduk Z, Ogorzałek A. 1978. Niphargellus arndti (Schellenberg, 1933) z jaskini Kontaktowej koło Kletna. Acta Univ Wratisl 3. Studia Geograficzne 24: 155-157.

Jaworowski A. 1893. Fauna studzienna miast Krakowa i Lwowa. Spraw Kom Fizyograf AU w Krakowie 28: 29-48.

Juberthie Ch, Decu V. (eds) 1994. Encyclopedia Biospeologica, vol. 1. Bucarest: Société de Biospèologie Moulis.

Kahl K, Pilipiuk I. 2004. Skąposzczety (Oligochaeta) In: Bogdanowicz W, Chudzicka E, Pilipiuk I, Skibińska E. eds. Fauna of Poland Characteristics and checklist of species. Warszawa: Muzeum i Instytut Zoologii PAN, pp. 9-17.

Kasprzak K. 1973a. Notatki o faunie skąposzczetów (Oligochaeta) Polski I. Fragm Faun 18: 405-434.

Kasprzak K. 1973b. Notatki o faunie skąposzczetów (Oligochaeta) Polski II. Fragm Faun 19: 1-19.

Kasprzak K. 1973c. Skąposzczety (Oligochaeta) wód interstycjalnych. Przegl Zool 17: 41-44.

Kasprzak K. 1975. Skąposzczety (Oligochaeta) osadów aluwialnych rzek. Prace Komisji Naukowych PTG III/16: 173-185.

Kasprzak K. 1976. Badania nad skąposzczetami (Oligochaeta) dolnego biegu rzeki Wełny. Fragm Faun 20: 425-466.

Kasprzak K. 1979a. Skąposzczety (Oligochaeta) Pienin. I. Wazonkowce (Enchytraeidae). Fragm Faun 24: 7-56.

Kasprzak K. 1979b. Skąposzczety (Oligochaeta) Pienin. Naididae, Tubificidae, Haplotaxidae, Lumbriculidae, Branchiobdellidae. Fragm Faun 24: 57-80.

Kasprzak K, Zajonc I. 1980. Skąposzczety (Oligochaeta) Tatr. Przegl Zool 24: 189-199. 
Knight LRFD, Brancelj A, Hänfling B, Cheney C. 2015. The groundwater invertebrate fauna of the Channel Islands. Subterr Biol 15: 69-94.

Košel V. 2009. Subteranna fauna Zapadnych Karpat. Czech Academy of Sciences: Česke Budějovice.

Krzanowski W, Fiedor E, Kuflikowski T. 1965. Fauna denna kamienisto-prądowych siedlisk dolnych odcinków Białego Dunajca, Rogoźnika i Lepietnicy. Zesz Nauk UJ 103, Prace Zoologiczne 9: 43-60.

Łuczak J, Rybak M, Ranke-Rybicka B. 1980. Występowanie organizmów wodnych w wodzie wodociągowej. Rocznik PZH 31: 319-325.

Mammola S, Cardoso P, Culver DC, et al. 2019. Scientists' Warning on the Conservation of Subterranean Ecosystems. BioScience 69: 641-650.

Martin P, De Broyer C, Fiers F, Michel G, Sablon R, Wouters K. 2009. Biodiversity of Belgian groundwater fauna in relation to environmental conditions. Freshwat Biol 54: 814-829.

Martínez-Ansemil E, Giacomazzi F, Sambugar B. 2016. Groundwater oligochaetes (Annelida: Clitellata) of the Dinaric region (SouthEast Europe). Biologia 71: 24-30.

Mary N, Marmonier P. 2000. First survey of interstitial fauna in New Caledonian rivers: influence of geological and geomorphological characteristics. Hydrobiologia 418: 199-208.

Meleg I, Campean M, Pavelescu C. 2009. Hyporheic fauna from the interstitial of the Somes river basin (Transylvania, Northwestern Romania). Trav Inst Spéol "Emile Racovitza" 48: 45-58.

Moszyński A. 1934. Skąposzczety (Oligochaeta) miasta Poznania. Kosmos ser. A 57: 235-255.

Moszyński A. 1936. Die Höhlenfauna des Glatzer Schneeberges. 9. Ein neuer Vertreter der Gattung Trichodrilus Clap. (Trichodrilus spelaeus nov. spec.) aus dem Stollen in Neu-Klessengrund. Beitr Biol Glatz Schneeberges 2: 214-216.

Olsen DA, Townsend CR. 2005. Flood effects on invertebrates, sediments and particulate organic matter in the hyporheic zone of a gravel-bed stream. Freshwat Biol 50: 839-853.

Ortuño VM, Gilgado JD, Jiménez-Valverde A, Sendra A, PérezSuárez G, Herrero-Borgoñón JJ. 2013. The "alluvial mesovoid shallow substratum" a new subterranean habitat. Plos One 8: e76311.

Pacioglu O. 2010. Ecology of the hyporheic zone: a review. Cave and Karst Science 36: 69-76.
Pawłowski LK. 1951. Pijawki (Hirudinaea) stacji pomp rzecznych oraz stacji filtrów w Warszawie. Fragm Faun Mus Zool Pol 6: 169-192.

Pax F, Maschke K. 1935. Die Höhlenfauna des Glatzer Schneeberges. 1. Die rezente Metazoenfauna. Beitr Biol Glatz Schneeberges 1: 4-72.

Skalski A. 1967. Characteristics of the recent fauna from the Szczelina Chochołowska cave in the Tatra Mts. Prace Muzeum Ziemi 11: 288-290.

Skalski AW. 1980. Studniczek lwowski, Niphargus leopoliensis Jaworowski, 1893 (Amphipoda) w Polsce. Przegl Zool 24: 97-101.

Sket B. 1999. High biodiversity in hypogean waters and its endangerment - the situation in Slovenia, the Dinarctic Karst, and Europe. Crustaceana 72: 767-779.

Sket B, Dovč P, Jalžić B, Kerovec M, Kučinić M, Trontelj P. 2001. A cave leech (Hirudinea, Erpobdellidae) from Croatia with unique morphological features. Zool Scr 30: 223-229.

Stammer H-J. 1936. Die Höhlenfauna des Glatzer Schneeberges. 8. Die Wasserfauna der Schneeberghöhlen. Beitr Biol Glatz Schneeberges 2: 199-214.

Starmach K, Wróbel S, Pasternak K. 1976. Hydrobiologia. Limnologia. Państwowe Wydawnictwo Naukowe, Warszawa.

Stubbington R. 2012. The hyporheic zone as an invertebrate refuge: a review of variability in space, time, taxa and behaviour. Mar Freshw Res 63: 293-311.

Sywula T. 1989. Bathynella natans Vejdovsky, 1882 i Proasellus slavus (Remy, 1948) nowe dla Polski, podziemne skorupiaki. Przegl Zool 33: 77-82.

Ter Braak CJF, Šmilauer P. 2002. CANOCO reference manual and CanoDraw for windows user's guide: Software for canonical community ordination (version 4.5), Microcomputer Power Ithaca, NY, USA

Williams DD, Febria CM, Wong JCY. 2010. Ecotonal and other properties of the hyporheic zone. Fundam Appl Limnol, Arch Hydrobiol 176: 349-364.

Williams DD, Hynes HBN. 1974. The occurrence of benthos deep in the substratum of a stream. Freshw Biol 4: 233-256.

Wood PJ, Boulton AJ, Little S, Stubbington R. 2010. Is the hyporheic zone a refugium for a aquatic macroinvetebrates during severe low flow conditions? Fundam Appl Limnol, Arch Hydrobiol 176: 377-390.

Cite this article as: Dumnicka E, Galas J, Krodkiewska M, Pociecha A. 2020. The diversity of annelids in subterranean waters: a case study from Poland. Knowl. Manag. Aquat. Ecosyst., 421, 16. 